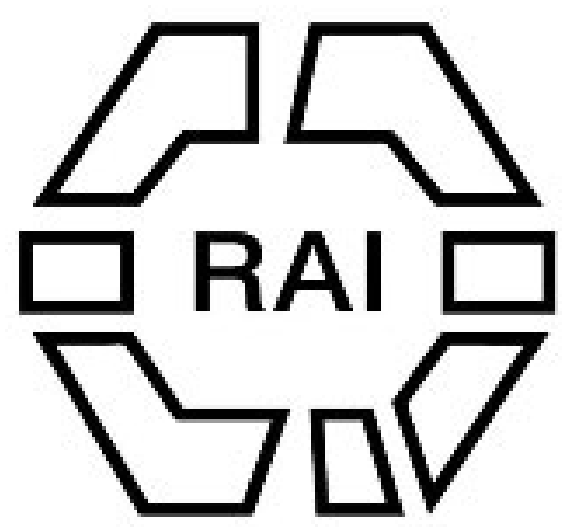

Bird-Chariots and Socketed Celts in Europe and China.

Author(s): C. G. Seligman

Source: The Journal of the Royal Anthropological Institute of Great Britain and Ireland, Vol. 50 (Jan. - Jun., 1920), pp. 153-158

Published by: Royal Anthropological Institute of Great Britain and Ireland

Stable URL: http://www.jstor.org/stable/2843377

Accessed: 10/06/2014 23:35

Your use of the JSTOR archive indicates your acceptance of the Terms \& Conditions of Use, available at http://www.jstor.org/page/info/about/policies/terms.jsp

JSTOR is a not-for-profit service that helps scholars, researchers, and students discover, use, and build upon a wide range of content in a trusted digital archive. We use information technology and tools to increase productivity and facilitate new forms of scholarship. For more information about JSTOR, please contact support@jstor.org. 


\title{
BIRD-CHARIOTS AND SOCKETED CELTS IN EUROPE AND CHINA.
}

\author{
By C. G. Seligman, M.D., F.R.S.
}

A PARTICULAR type of wine vessel on wheels, representing a bird, has long been familiar to those interested in Chinese bronzes. The type, well represented by a specimen in the Victoria and Albert Museum (No. 183-'99, figured by Bushell, Chinese Art, I, Fig. 56), is called by the Chinese chiu ch'ê tsun, "dove-chariot vase," and according to the Japanese manual the Shin-Sho Sei, is as old as the Han dynasty (B.c. 206-220 A.D.). "The bird of mythological aspect, which is supposed to represent a dove (chiu), has its tail curved downwards, and a trumpet-shaped vase-mouth strengthened by vertical ridges on its back; it is engraved with scroll ornament and dragons, and displays on its breast a grotesque head moulded in relief. Two wheels support it at the side, and a smaller one at the tail, adapting it to circulate on the altar during the performance of ancestral ritual ceremonies." 1 Fig. 1 is a reproduction from the Shin-Sho Sei (Part I, p. 19) of an example of this type of vessel, said to be of Han age.

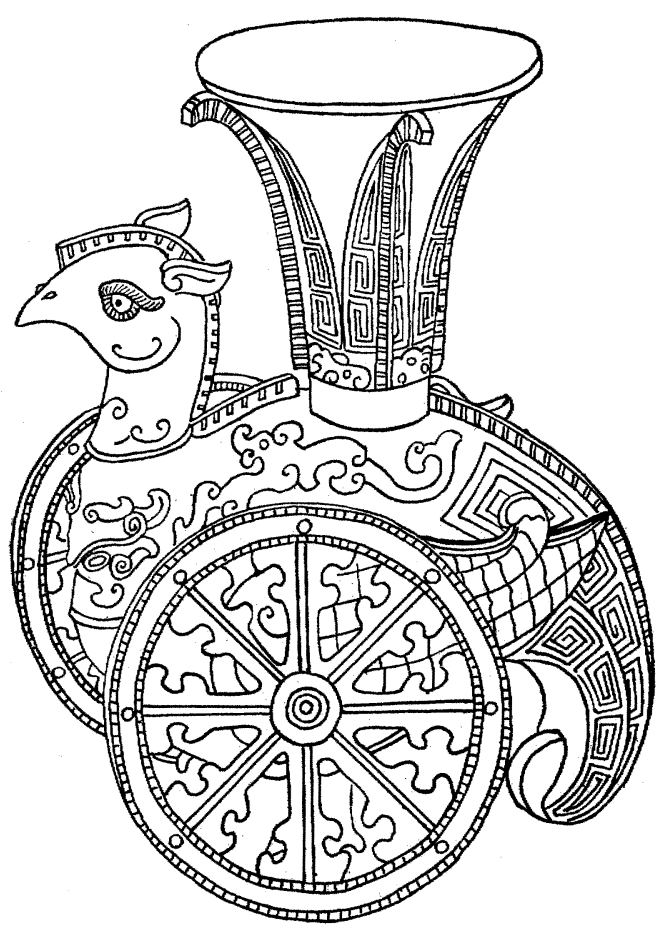

FIG. J.

1 Bushell, op. cit., I, pp. 91, 92. 
I have not been able to learn the precise purpose to which these vessels were applied, but from Bushell's statement they are or were used in the ceremonies of ancestor worship. Their shape is sufficiently remarkable to induce speculation as to their origin; it is true that birds and animals on wheels occur elsewhere, notably in Central and Northern Europe during the Bronze Age, but from here to China seems a far cry, and it is only lately that I have recognized that there is evidence which points to definite cultural communication between Europe and China in the Bronze Age. This evidence is offered by the distribution of the socketed celt. This essentially European tool is absent from Egypt, Asia Minor, Iran and India. ${ }^{\mathbf{1}}$

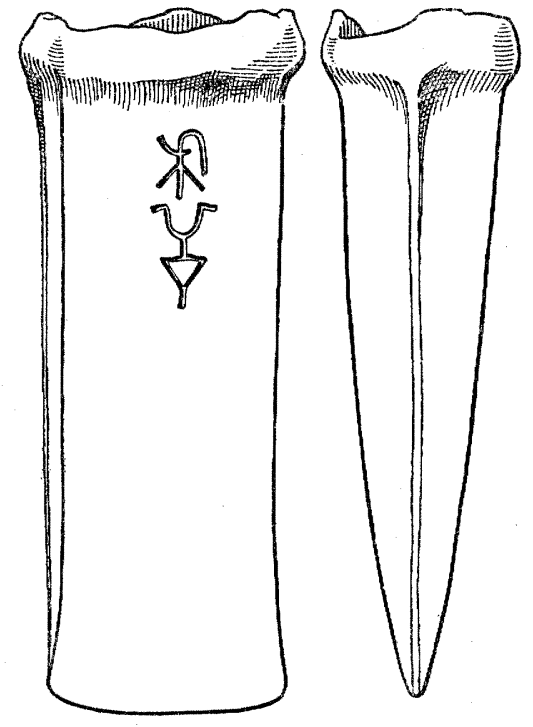

FIG. $2 . \times$ c. $\frac{1}{2}$.

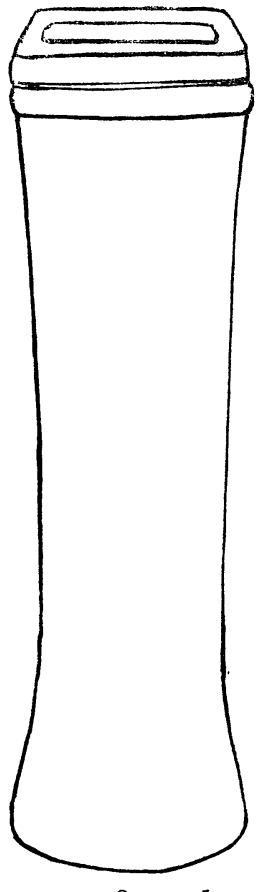

FIG. 3. $\times \frac{1}{2}$.

It occurs in Southern Russia (the Ukraine), in Siberia (especially in khurgan of the Yenesei basin), in the northern Shan States, in Burmah, Cambodia and in China. Here they have been found both in the south (Yunnan) and the north (Tsinanfu), while certain specimens are inscribed with an archaic form of script which may well be dated to the Chou dynasty (B.c. 1122-225). An example (Fig. 2) in the British Museum (1911, 10-25.5) bears two characters; no specimen is figured in the Pokutu or in the Shin-Sho Sei, but I am indebted to Mr. B. J. Koop alike for referring me to the representation of the specimen figured in the Tuan Fang Catalogue and for the copy of this which is here reproduced (Fig. 3).

1 The authority for this statement, as far as Asia Minor, Iran. and India are concerned, is Déchelette, cf. Manuel d'Archaeologie, II, p. 254. 
This distribution indicates that the socketed celt reached China by a transSiberian land route, and not south of the Himalaya or by sea.

I may now return to the "bird-chariot," as Déchelette calls the bird on wheels. The European form differs from the Chinese dove-vases in that the birds are mounted on four wheels as in the excellent example portrayed by Hoernes ${ }^{1}$ (reproduced, slightly modified, as Fig. 4 of this note), or when this is not the case are perched on the $Y$-shaped prolongation of the pole attaching the latter to the axle of the two-wheeled chariot, which in form rather resembles a gun carriage, the socket for the pole representing the trail.

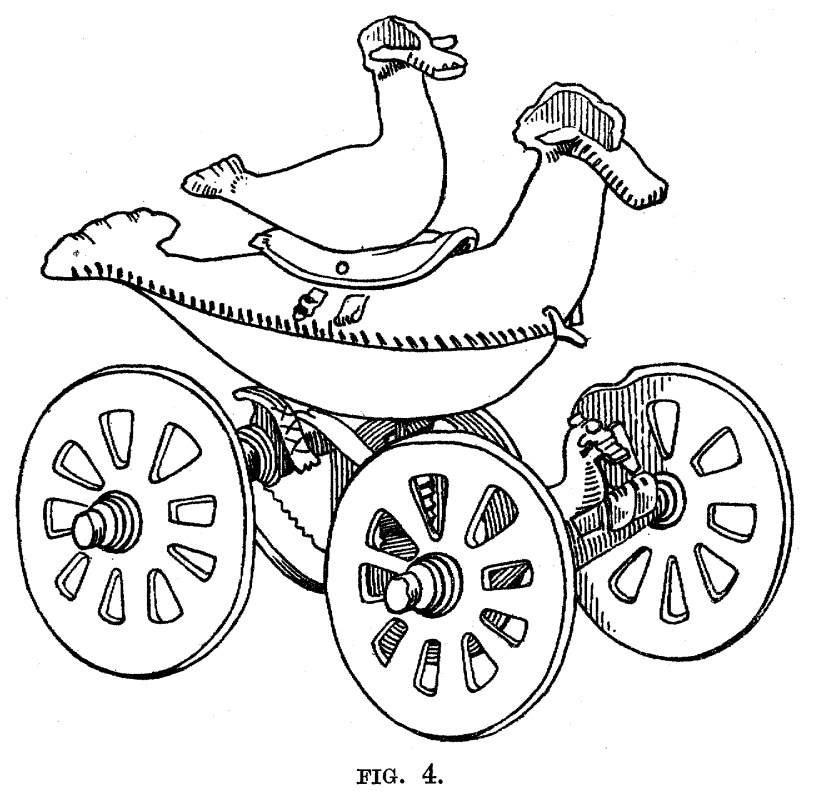

Animal- as apart from bird-chariots are of course well known, the most celebrated being the Trundholm solar chariot with a horse on wheels drawing a representation of the sun disc.

All these European chariots are of the Bronze Age ; according to Montelius, the Trundholm chariot dates to about 1300 B.c. ${ }^{2}$ It may be presumed that the birdchariots are approximately of the same date, while according to Déchelette it is to the fourth and final period of the Bronze Age, lasting from 1300 to 900 B.c., that the socketed celt must be attributed. ${ }^{3}$

Besides the "dove-chariot vase" there is another form of bird on wheels figured in the Pokutu (Vol. 27, pp. 44 and 45), and also in the Shin-Sho Sei, reproduced here as Fig. 5. This is a naturalistic representation of a bird which may well

1 Natur und Urgeschichte des Menschen (1909), II, Fig. 207.

${ }^{2}$ Déchelette, op. cit., II, p. 416.

3 Ibid., p. 106. 
represent a pigeon or a dove, but it bears one or two entirely unnatural representations of smaller birds (I shall speak of these as accessory birds, they may perhaps be thought to represent its young) on its back or breast. It is slung low between two wheels, does not bear a vessel on its back or any conventional pattern, the surface of the

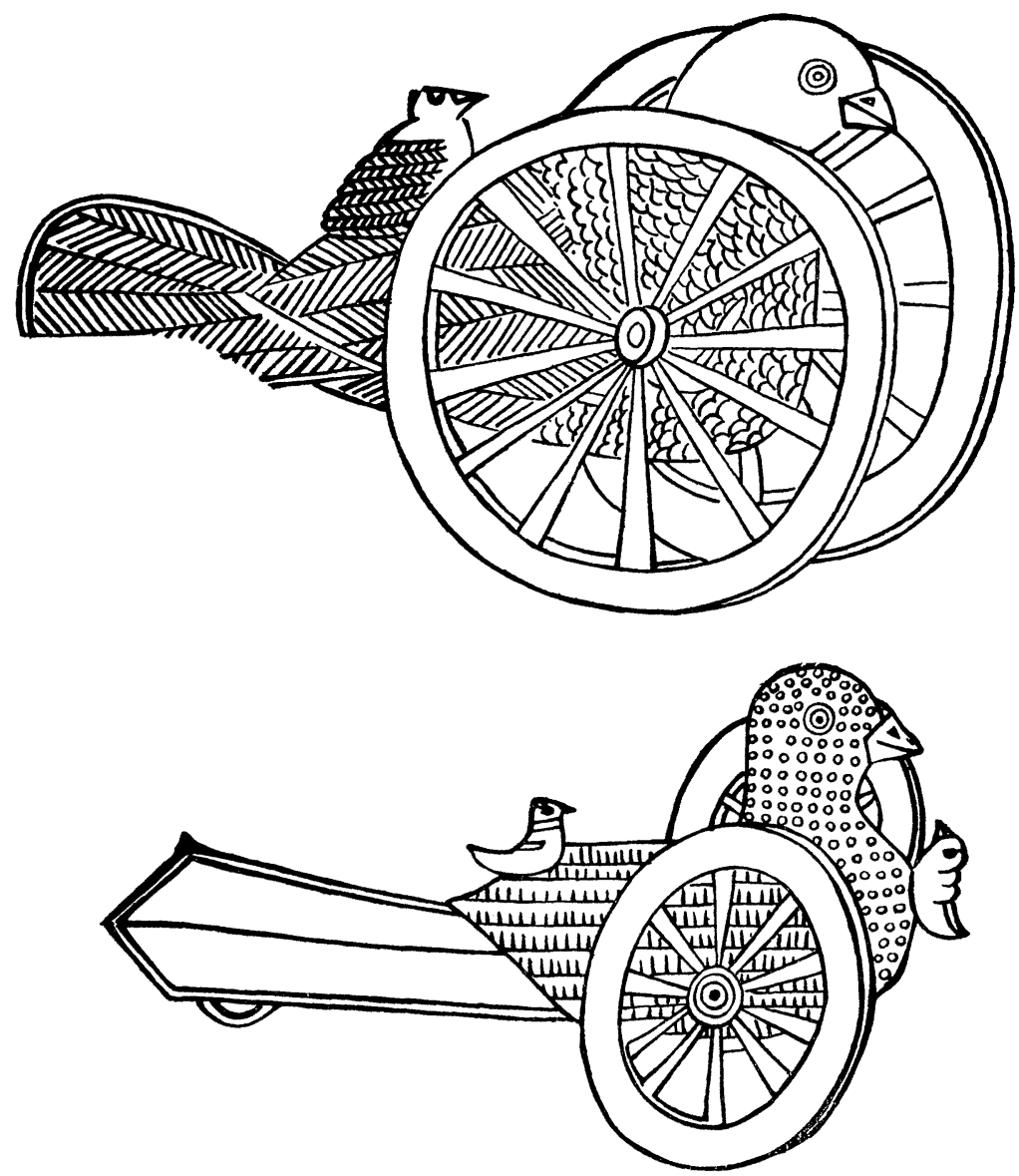

FIG. 5 .

body being graved to give a more or less naturalistic rendering of the feathers. According to Chinese authorities, this form of bird-chariot also dates from the Han period.

Turning to the European example of Bronze Age date (Fig. 4) it will be noted that a small and not very obvious bird is represented between the front wheels of the chariot, and that the lid covering the opening in the body of the main bird supports a smaller bird of similar type.

The resemblance of the small accessory birds of the T'ang bronzes to these subsidiary birds of the European bird-chariot is very striking, and considering the migration of the socketed celt from West to East can scarcely be accidental, but 
must, I suggest, be attributed to transmission during the latter part of the Bronze Age.

There is even a parallel to the Trundholm chariot to this extent, that although animal-chariots are not, as far as I can ascertain, figured in any ancient Chinese work, there is in the Cernuschi Museum in Paris a ram on wheels, and though this specimen is archaistic rather than archaic, it at least shows that animal- as well as bird-chariots are not unknown to the Chinese, though, as pointed out to me by Mr. Koop, it may be a late copy, the wheeled base being an addition not contemplated at an earlier date. Concerning this specimen I am indebted to M. d'Ardenne de Tizac, Conservator of the Museum, for the following particulars. It stands about $30 \mathrm{~cm}$. high, and is $45 \mathrm{~cm}$. in length ; head and feet bear a conventional design. The body, which is hollow, is graved with a scale design, and in the middle of the back is a movable lid bearing a grasshopper as handle; M. de Tizac considers that the specimen is of T'ang age, though of an older type.

Lest it should be thought that I have laid too much stress on the actual morphological similarities in these Western and Eastern bird-chariots and that these may be due to coincidence, let me adduce another piece of evidence showing the persistent linkage of the bird and chariot as well as the tendency of the two to spread together into foreign cultures. The cauldron on wheels, or the cauldron-chariot, as it may be

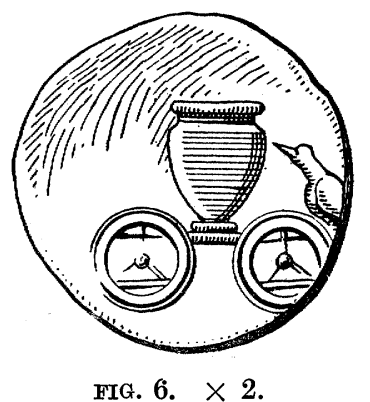

called, is a well-known Bronze Age antiquity of Central and Northern Europe. ${ }^{1}$ This became associated with birds as in the example in Vienna Museum, ${ }^{2}$ and this association was so strong that it persisted at least until the third or fourth century B.C., for on some of the coins of the Greek city state Krannon-as that represented in Fig. 6-there is represented a jar occupying the space between the wheels of a chariot, upon one of which there perches a bird.

Conclusions.-(1) The bird-chariot in China, as shown by native records, is of considerable but not extreme antiquity, probably dating back some two thousand years.

1 Cf. e.g., Déchelette, op. cit., II, Fig. 107, p. 285.

${ }^{2}$ Figured by Déchelette, op. cit., II, Fig. 183, p. 442. 
(2) It is not Chinese in origin, but was derived from the bird-chariots of the later Bronze Age of Europe.

I desire to express my thanks for much kindly help to Messrs. Reginald Smith and R. L. Hobson, of the British Museum, and to Mr. A. J. Koop, of the Victoria and Albert Museum, without which it would have been impossible to give the necessary precision to the idea here set forth. I am also indebted to Mr. L. C. Hopkins for endeavouring to read the characters on the socketed celt in the British Museum.

Postcript.-Since putting together the above paper 1 have become aware of a paper by Berthold Laufer, "The Bird-Chariot in China and Europe," published in the Boas Anniversary Volume (New York, 1906). Laufer figures the two dove-chariots of T'ang age reproduced in this paper, but besides these, he also reproduces another example of white nephrite from the Illustrated Book of Ancient Jades, which was compiled in 1176 and published in 1779. Moreover, he figures a third bronze dovechariot of 'T'ang age from the Hsi' ch'ing ku chien (the great catalogue of Kien Lung), with three small accessory birds, obviously representing the young, since one of these, clinging to the mother bird's breast, is beak to beak with it as though being fed.

Laufer (op. cit., p. 421), in discussing the significance of the Chinese dove-chariot, points out that the native records indicate that it was unknown in the days of greatest antiquity, and that it " did not make its appearance before the era of the Han dynasty -a period in Chinese art in which large waves of foreign elements burst over the native ideas. It was the time when . . . Siberian or old Turkish art exercised a far-reaching influence on that of China, and new motives imported from abroad held full sway over the then Chinese artists."

As I have done, he suggests a connection between these dove-chariots and the European cult-chariots of the Bronze Age, but considers that not much stress should be laid on this similarity since "uniportunately, among the antiquities of Siberia no such bird-chariots have hitherto been discovered."

Laufer makes no mention of the socketed celt of bronze, nor does he specially draw attention to those European bird-chariots, such as that shown in Fig. 4 with a smaller bird as lid handle on its back, which so well explain the accessory birds on the dove-chariots figured by both of us. 